\title{
Polenblut. Images of Poland and the Poles in German Operetta
}

\author{
Ryszard Daniel GolianeK \\ Adam Mickiewicz University, Poznań \\ U1. Słonecznikowa 25/5 \\ PL-62-080 Tarnowo Podgórne, Poland \\ E-mail:degol@amu.edu.pl
}

(Received: March 2016; accepted: June 2016)

\begin{abstract}
Among the wealth of German operettas, an important place is occupied by works referring to Polish subjects in their plots, or featuring Polish characters. The moral judgments passed on the persons of the drama frequently reveal generalisations concerning large communities or even entire nations. At the present stage of research, I can confirm the existence of about a dozen German operettas containing Polish motives. For my analysis, I have selected three operettas: Polnische Wirtschaft, Polenblut and Die blaue Mazur, composed in more or less the same period - the 1910s. An analysis of characters and topics recurring in these operettas proves that certain prejudices and stereotypes play a major role in the construction of events and the characterisation of dramatis personae. An important role in the creation of national stereotypes is also played by musical categories associated with Polish culture, mainly national dances - the krakowiak and the mazur. The three stage works discussed in this paper, created in a period of historical transformation associated with Poland's rebirth as an independent country, appear to offer excellent arguments in the ongoing debate on the role of national stereotypes in communication between neighbouring nations.
\end{abstract}

Keywords: German operetta, Poland, Polish themes, national stereotypes

The operetta as a genre rarely attracts the interest of musicologists. This is partly due to the repetitive, conventional style of this music, as well as the fact that it is intended for the mass bourgeois audience, with its rather unsophisticated musical tastes. In German-speaking cultural circles, the heyday of the operetta can approximately be dated to $1870-1945$, that is, the period when categories of national identity and state affiliation were strongly articulated in both politics and social debates. In bourgeois culture of the late nineteenth and early twentieth centuries, 
the operetta played a major role, as it developed and promoted national and local self-identification and standpoints. Its links with everyday life phenomena and social behaviour are evident in the choice of subject matter, in the preferred types of value judgment and the representations of both desirable and criticised attitudes. ${ }^{1}$

Berlin and Vienna became the main centres of the German-language operetta in the late nineteenth century. From there, the rich operetta repertoire reached the German and Austrian provinces as well as the annexed and dependent countries, such as the Czech territory, Hungary and Poland. This repertoire was characterised by the strong presence of characters and motives associated with national and ethnic minorities. The operetta played a major role in the process of integrating those minorities, acting as an educational tool and an intermediary, familiarising the society with the lights and shadows of multiculturalism and national diversity. A similar function was fulfilled in the interwar period by the cabaret, whose development contributed to some extent to the decline of the operetta after World War II.

Among the wealth of German operettas, an important place is occupied by works referring to Polish subjects in their plots, or featuring Polish characters. The dominant - though not the only - way of presenting Poles in the operetta was to confront them with representatives of the German society. Marked differences of behaviour and personality between the characters frequently generate dramatic conflicts in the action of the musical play. The way those characters are represented testifies to the presence of stereotypes concerning the different nations, while the moral judgments passed on the persons of the drama frequently reveal generalisations concerning large communities or even entire nations. In this respect, German operettas on Polish subjects deserve closer attention, since by analysing those works I can reconstruct the image of the Poles common in the German society in that period, as well as measuring the temperature of mutual relations between the two coexisting nations. This is the most important aspect of the operettas in questions. ${ }^{2}$ In individual stage works, it is also highlighted on the

1. The musicological literature devoted to the genre of operetta seems relatively limited. For a broader context of this subject and a better understanding of the social and political roles of operetta see: Moritz Csáky, Ideologie der Operette und Wiener Moderne. Ein kulturhistorischer Essay zur österreichischen Identität (Wien: Böhlau, 1996); Camille Crittenden, Johann Strauss and Vienna: Operetta and the Politics of Popular Culture (Cambridge: Cambridge University Press, 2000); Warum es der Operette so schlecht geht: Ideologische Debatten um das musikalische Unterhaltungstheater (1880-1916), ed. Marion Linhardt (Wien: Böhlau, 2001); Richard Traubner, Operetta: A Theatrical History (New York: Routledge, 2003); Volker Klotz, Operette. Porträt und Handbuch einer unerhörten Kunst (Kassel: Piper, $\left.{ }^{2} 2004\right)$.

2. The problem of Polish themes in operetta was partially described in Oswald Panagl, "Solang 's noch solche Frauen gibt, ist Polen nicht verloren. Identitätskrisen und Solidaritätsstiftung auf der Operettenbühne," in Politische Mythen und nationale Identitäten im (Musik-)Theater. Vorträge und Gespräche des Salzburger Symposions 2001, ed. Peter Csobádi et al. (Anif/Salzburg: Mueller-Speiser, 2003), vol. 2, 829-842. The author takes into consideration the following four operettas: Der Bettelstudent (1882) by Carl Millöcker, Polenblut (1913) by Oskar Nedbal, Der letzte Walzer (1920) by Oscar Strauß and Die blaue Mazur (1920) by Franz Lehár. The title of his article was borrowed from the lyrics of Polenblut (no. 7 Marschlied: "Brüder, ich bin verliebt"). 
musical level through the introduction of Polish national dances, quotations from, or stylisations of, Polish music.

The vast repertoire of German operettas containing Polish motives calls for an in-depth study and systematic description. At the present stage of research, I can confirm the existence of about a dozen such compositions whose action involves Polish characters, while the plots frequently reflect the Polish-German social relations. The list of eleven operettas presented below is the result of preliminary research to date and is presumably incomplete. Further studies will most likely uncover other such works in the same genre.

TABLE 1 German operettas on Polish subjects

\begin{tabular}{|l|l|l|l|}
\hline & Composer & Title & Premiere \\
\hline 1. & Carl Millöcker & Der Bettelstudent & Vienna 1882 \\
\hline 2. & Rudolf Dellinger & Jadwiga & Dresden 1901 \\
\hline 3. & Victor Hollaender & Der Sonnenvogel & Berlin 1904 \\
\hline 4. & Jean Gilbert & Polnische Wirtschaft & $\begin{array}{l}\text { Cottbus 1909, } \\
\text { new version: Berlin 1910 }\end{array}$ \\
\hline 5. & Oskar Nedbal & Polenblut & Vienna 1913 \\
\hline 6. & Franz Lehár & Die blaue Mazur & Vienna 1920 \\
\hline 7. & Oscar Straus & Der letzte Walzer & Leipzig 1920 \\
\hline 8. & Bruno Wilhelm Goehr & Oberschlesische Mädchen & Hindenburg/Zabrze 1924 \\
\hline 9. & Ralph Benatzky & Zirkus aimée & Berlin 1932 \\
\hline 10. & Joseph Beer & Die polnische Hochzeit & Zurich 1937 \\
\hline 11. & Willy Czernik & Die schöne Carlotti & Prague 1943 \\
\hline
\end{tabular}

The role of Polish elements in the listed operettas varies from one work to another. ${ }^{3}$ In some of them, those elements determine the main course of events, while in others they are but marginal additions introducing local colour. As analytic material, I have selected for the purposes of this paper three operettas: Polnische Wirtschaft, Polenblut and Die blaue Mazur. All of them were composed in more or less the same period - the 1910s, a time of fundamental social and political change. Since none of these stage works is particularly popular, it has been deemed necessary to present brief resumes of their action and themes.

3. Oswald Panagl tries to distinguish a particular type of a "Polish genre" in operetta, characterized by a few common elements such as national pride of the main characters, resistance against foreign powers, political ties in the time of trouble and a felicitous ending (at least in the private sphere). "Im goldenen wie im silbernen Segment der österreichischen Operette lässt sich eine Nische ausmachen, die man als polnisches Genre bezeichnen könnte. Denn abseits aller zeitlichen und stilistischen Unterschiede und zusätzlich zum gemeinsamen Schauplatz gibt es einige durchgehende Merkmale: nationaler Stolz der Protagonisten, Widerstand gegen Fremdbestimmung, politischer Zusammenhalt in schwierigen Zeiten, schließlich - der Gattung gemäß - ein guter Ausgang, der zumeist privates Glück und öffentliche Wohlfahrt auf einen Nenner bringt.” Panagl, "Solang's noch solche Frauen gibt," 839. 
Polnische Wirtschaft is set in Berlin and in a declining country estate in Greater Poland (then Großherzogtum Posen), whose owner - Willy Hegewaldt - separated from his Polish wife Marga, plans a new marriage to Erika, daughter of the Berlin city councillor Mangelsdorf, but property rights prove to be an obstacle. Marga had inherited Groß-Karschau from her aunt, whose last will contains some peculiar clauses that force Willy and Marga to play a "happy couple" lest their property should be forfeited to other members of the family. Every year on 30 August all the relatives arrive at Groß-Karschau to control the conjugal welfare of the pair. During a family reunion, Willy and Marga pass themselves off as an exemplary married couple. After some twists and turns, Willy makes up his mind to return to Marga, and the abandoned Erika accepts the hand of the poet Hans Fiedler, whom Marga has sent to Berlin so that he would persuade her husband to come back home.

The protagonist of Polenblut, Graf (Count) Boleslaw (Bolo) Baranski has a good time in Warsaw during carnival, neglecting his declining estate at Krasnowola. He is to court Helena, the resourceful and enterprising daughter of a family friend, Jan Zaremba, but he would much rather enjoy his party-going lifestyle and the company of Wanda, dancer of the Warsaw Opera. The disappointed Helena resorts to deceit: some time later she arrives at Krasnowola with Bolo's friend, Bronio von Popiel. Bronio introduces her as Marynia, an energetic housekeeper in search of employment. Bolo takes her on, and she quickly manages to improve the condition of the manor. Satisfied and progressively more and more fascinated, Baranski even intends to marry her, disregarding the difference of birth and fortune, when the dancer Wanda comes from Warsaw and reveals the truth: this excellent housewife is Helena, who has employed such a stratagem to win Baranski's heart. The proud Helena intends to give up her marriage plans, but Bolo prevents her departure and asks for her hand. Wanda, frustrated in her hopes, has no choice but to start a relationship with Bronio.

The mazur of the title plays a special role in the finale of Die blaue Mazur, which marks the happy ending for the protagonists: Graf (Count) Julian Olinski and his young wife Blanka von Lossin. Though the plot begins with their wedding, it soon turns out that Julian misses the cheerful lifestyle and numerous women that he has to part with. Learning about this by accident, the desperate Blanka requests the help of Freiherr (Baron) von Reiger, an old friend of her mother's. The nobleman offers her shelter in his house, which he shares with his nephew, who leads a double life: that of the respectable and hardworking Engelbert by day, and that of the debauchee Adolar by night. After some time Julian discovers Blanka's whereabouts and attempts to win her back by a stratagem: he offers to annul their marriage and restore freedom to Blanka, who had meanwhile become fascinated with Engelbert. When it turns out, however, that Engelbert and Adolar are one and the same person, Blanka jilts him, and he seeks solace with the dancer 
Gretl. Blanka realises that she loves her husband, and decides to forgive him. The reconciliation scene takes place at a ball - during a mazur, Julian is reunited with his wife. The title ought actually to be translated as The White Mazur, as it refers to the Polish custom of the man asking the lady of his heart to be his partner for the last dance of the ball.

The choice of the main persons of the drama for the three operettas seems strikingly similar, which suggests that they all follow a certain stereotype of character construction. The main male figure is a nobleman, slightly lost and confused, a wastrel type, who puts the pleasures of life over daily responsibilities. Additionally, Julian Olinski and Boleslaw Baranski bear stereotypical Polish names and surnames. This type, focusing on simple pleasures of the wine-women-and-song kind, eventually abandons the world of sensual pleasures and converts to a life of bourgeois virtues by (re-)uniting with a positive heroine.

The portraits of the female characters in each of the operettas are conventional and highly simplified. The drama pivots around two indispensable female figures, acting as polar opposites. The first one is a sensible and conscious woman, the perfect stereotype of a wife: loving, responsible, thrifty, and willing to accept sacrifices. Helena, Blanka and Marga are active figures who care about their relationships with their somewhat irresponsible partners, and resort to intrigue or stratagems in case of trouble. The other type of female character follows the operetta cliché of a lover or kept woman and a demimondaine. She is attractive, unassuming and committed to a life of pleasure. It is not a coincidence that both Gretl and Wanda dance in the theatre, which in the bourgeois worldview was an environment associated with immorality and eroticism.

This triangle of protagonists is complemented by two other male characters. One is a young wastrel or daydreamer, frequently - the protagonist's companion. His material, professional and moral status is unclear, which situates him among the comic or farcical figures. In the course of dramatic action, he finds himself in the role of the partner of the protagonist's rejected lover. The last of the main persons of the drama is an elderly aristocratic mentor, an embodiment of old-fashioned bourgeois virtues and principles: Baron von Reiger or the nobleman Jan Zaremba.

TABLE 2 The protagonists of the operettas

\begin{tabular}{|l|l|l|}
\hline \multicolumn{1}{|c|}{ Dramatic function } & \multicolumn{1}{|c|}{ Characteristics } & \multicolumn{1}{c|}{ Character } \\
\hline $\begin{array}{l}\text { A nobleman, the } \\
\text { main character }\end{array}$ & $\begin{array}{l}\text { oscillating between a life of } \\
\text { pleasure and a bourgeois lifestyle }\end{array}$ & $\begin{array}{l}\text { Willy Hegewaldt, Bolo Barański, } \\
\text { Julian Oliński }\end{array}$ \\
\hline His beloved or wife & conscious, perfect & Marga, Helena, Blanka \\
\hline His lover & usually a dancer & $\begin{array}{l}\text { Erika, Wanda Kwasińska, Gretl } \\
\text { Aigner }\end{array}$ \\
\hline His friend & a comic wastrel & Bronio Popiel, Adolar/Engelbert \\
\hline A mentor & an old-fashioned aristocrat & Jan Zaremba, Baron von Reiger \\
\hline
\end{tabular}


An analysis of topics recurring in these operettas proves that certain prejudices and stereotypes play a major role in the construction of events and the characterisation of dramatis personae. One of the protagonists in all these plays is a Polish landowner, who epitomises all the negative qualities that Germans associated with the Poles: he is a poor manager, wasteful, undisciplined and irresponsible, but endowed with romantic personality traits and respectful of the traditions of the past. Julian and Boleslaw are unwilling to give up their partying lives. However, when they finally choose the right woman, they win her (back) in a refined manner, following time-honoured custom. At the end of Act I of Die blaue Mazur, Julian sings (in Polish) a nostalgic dumka about his beloved, and in the finale he dances the white mazur with Blanka. Bolo, the protagonist of Polenblut, follows the Polish tradition in making Marynia (Helena) the queen of the harvest festival and adorning her head with a crown made of ripe ears of grain.

The characterisation of Blanka, Helena and Marga is also interesting. Though in their case national identity is not a central issue, the national stereotypes are nevertheless detectable. The affectionate Blanka of Die blaue Mazur - a Viennese aristocrat - despite her somewhat supercilious and one-sided stage presentation, is nevertheless a sensitive, romantic woman. At first the behaviour of her irresponsible Polish husband causes her to recoil, but soon her subtle personality and readiness for sacrifice win the upper hand and she leads the count back onto the path of virtue. There is no doubt that this kind of character portrayal was understood in a wider perspective as a metaphor of the national character, supporting the claim that the irresponsible Poles ought to be managed by the incomparably more civilised Austrians. This may have been the message conveyed to the Viennese audience, which also offered an oblique justification of the history of political relations between the two nations.

In the dramatic construction of Polenblut, national undertones appear to be much more subtle, as here all of the characters are Poles and the Polish-German relations are not openly referred to. Nevertheless, a closer analysis if this aspect of the work leads to much less obvious and unequivocal conclusions. Both Krasnowola - Baranski's impoverished estate - and Warsaw are situated in the territory annexed by Russia under the Partitions, but Helena and her father do not belong to this social environment. Though the librettist does not tell us directly that they come from Austria-Hungary, their exaggerated and unambiguously positive features of character are those stereotypically identified with German or Austrian virtues. To the audience, this must have been a clear indication of their origin from outside the Russia-occupied lands. In a way, such a stereotypisation of characters sanctioned the rule of the partitioning states in the former Polish-Lithuanian Commonwealth.

The role of Marga in the dramatic makeup of Polnische Wirtschaft should be associated, on the other hand, with the situation under Prussian rule. Her strongly 
marked responsible attitude, as well as the peculiar clause in her aunt's last will, are manifestations of the organising and strongly ordering historical impact of Prussian culture in the Polish lands. What is interesting in this context is that Marga herself is firmly convinced of the strength of a Polish woman's personality:

Tanzt die Polin, Pulse fliegen,

Männer alle wir besiegen,

Temp'rament ist kolossal,

Liebesqual gleich überall!

Polin hat von allen Reizen,

Andre damit einzeln geizen,

Exquisitesten voran,

Sagt doch jeder Mann. ${ }^{4}$

The manner in which the Polish characters are presented in these operettas, as well as the descriptions of local customs and traditions - are what makes their plots credible to the audience. The harvest festival, the white mazur, greeting the newlyweds with bread and salt, or the annual family reunions - are elements of the local colour. Still, national stereotypes are also reinforced in other ways in these stage works. Their very titles contain hints at a specific national characterisation. Die blaue Mazur refers to a custom of the Polish nobility associated particularly with the military circles, and therefore an element of the Polish cultural code accepted and propagated in the multinational environment of the Habsburg Monarchy. The titles of the other two operettas require a more detailed analysis, as they expressly point to the Polish context. The term Polnische Wirtschaft has a pejorative connotation, and in the nineteenth century it became a synonym for disorder and lack of proper organisation. Mismanagement, self-interest, lack of responsibility and of stable economic principles were the features of an economy that - according to the stereotypical German view - caused Poland's political downfall. The term is still used in contemporary German language for what is seen as the Poles' inherent lack of economic sense, resulting in moral decay and chaos.

The word Polenblut used in the title of Nedbal's operetta is equally telling: it refers to the Polish temperament and to the personalities of the protagonists. The title might allude to Helena's energy and initiative, though the Austrian audience would much more likely have recognised features of the Polish national character in the other persons of the drama: the thriftless Baranski, his parasitic friend Bronio and the wanton dancer Wanda. However, Helena's crucial function in the dramatic development of this operetta suggests a different interpretation of the title, associated with promoting a new approach to the concept of Polishness. The

4. Polnische Wirtschaft, finale of Act I, no. 3, Marga's part.

Studia Musicologica 57, 2016 
positive portrayal of Helena illustrates the kind of "grass-roots work" that created a different image of the Poles, of their educational and civilizational status.

The text spoken or sung by the characters includes many passages in Polish, which evidently served to authenticate the dramatic action. Still, these Polish-language elements are limited to short phrases or isolated sentences, aiming to familiarise the listener with some Polish national characteristics:

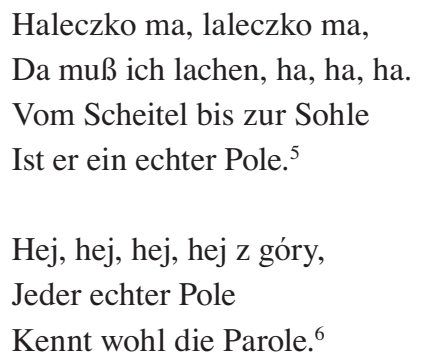

There are even some dialectal expressions which may be interpreted as stylisations of local spoken language. For instance, Marga - from Greater Poland - sings in the finale of Act II of Polnische Wirtschaft about ,pinunze” (money).

Zum Tanz, zum Tanz,

Frei will ich sein!

Da habt Ihr pinunze!

Cze kuje! Bardzo cze kuje!

An important role in the creation of national stereotypes is played in the three stage works under study by musical categories associated with Polish culture. The dominant elements are popular "trademarks" of Polish music, mainly national dances - the krakowiak and the mazur - introduced in order to characterise persons of the drama and the scenes in which they appear. Without a doubt, the presence of such musical elements, perceived as specifically Polish, decided about the attractiveness of these stage works and about their Polish colour. To some extent, they could also serve to authenticate the national topics present in the operettas.

The mazur obviously plays a major role in the action of Die blaue Mazur. It appears not only in the final dance, but in a few other passages earlier on, where it seems to be specifically associated with Julian and his Polish environment. The well-written dance stylisations highlight the Polish provenience of the protago-

5. Polenblut, duet, no. 4.

6. Polenblut, finale of Act I.

7. Polnische Wirtschaft, Act II, Marga's part. The proper literary Polish forms would be "pieniądze" (instead of "pinunze") and "dziękuję" (instead of "cze kuje"). 
nists as well as suggesting Polish features of character and behaviour, as in the duet of Julian and Blanka - "Tanzt der Pole die Mazur".

Example 1 Die blaue Mazur - Polish dance stylisation (the mazur) ${ }^{8}$

Tempo di Mazurka
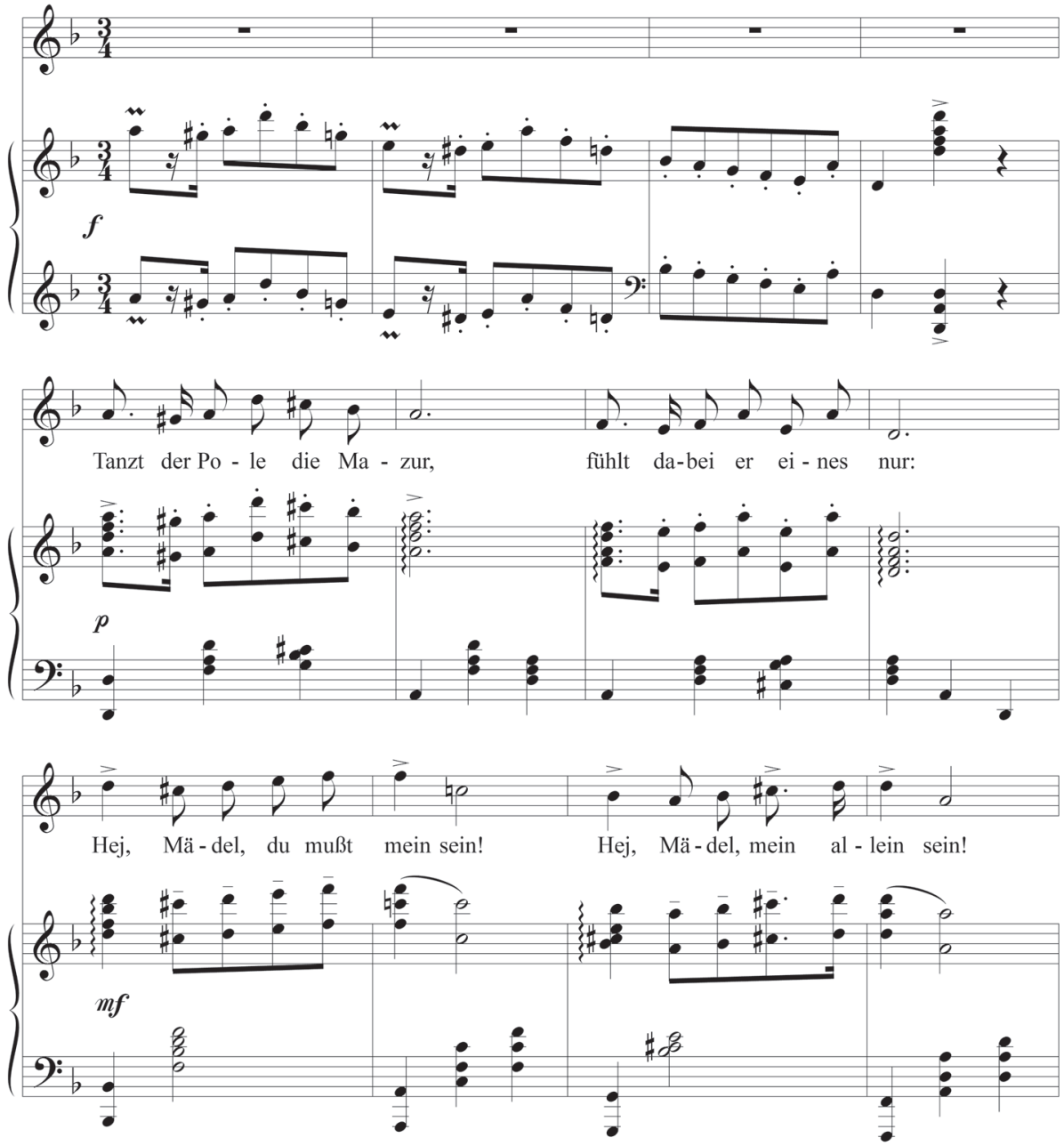

8. Act III, no. 13. Source: Leo Stein, Bela Jenbach and Franz Lehár, Die blaue Mazur. Operette in zwei Akten, drei Bildern (Wien: Glockenverlag, 1920/1948), 90. 
The mazur, the mazurka and other Polish dances also appear in the other two works under study. I coyyuld therefore assume that these stylisations reflect a more general tendency toward the stereotypical representation of Polishness in the genre. In this context, it may be worthwhile to consider the other Polish national dances present in these stage works. The polonaise - the most important of Polish dances - can only be found in the initial sections of Die blaue Mazur, whereas in Polenblut we relatively frequently discover the rhythms and characteristic idiom of the krakowiak. Since the action is set in the Russian-occupied territory, the presence of this dance could be seen as yet another hint at Helena's presumed Galician descent. Another such a clue is the vignette of the first edition of the piano transcription, which shows the protagonists of the operetta in national costumes from the Kraków region.

Plate 1 Polenblut - vignette (cover) of the piano score (first edition, 1913),

Copyright by Ludwig Doblinger K.G., Vienna, with kind permission of the publisher

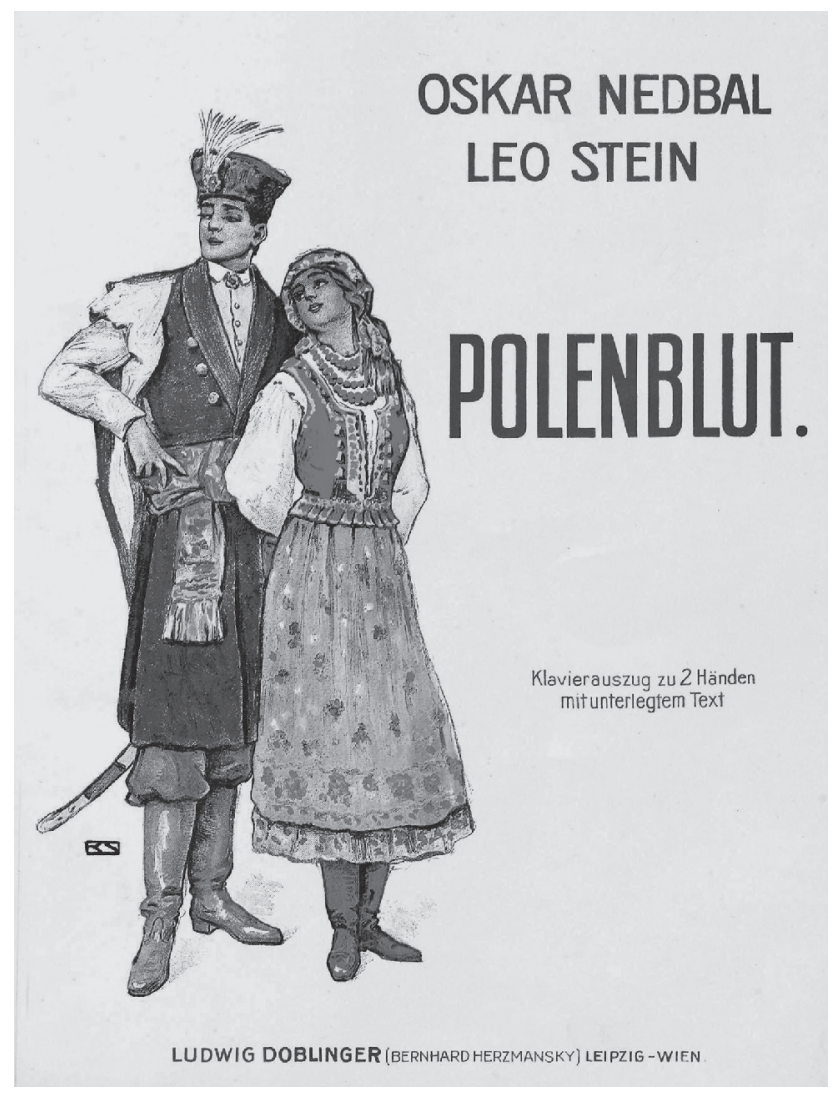


Polenblut also contains other Poland-related musical stylisations, which go beyond the typical use of national dance rhythms. The harvest festival scene in Act III provides the best opportunity for introducing such elements. Apart from the march-like stylisation of a village band (Marsch der Dorfmusikanten), we hear the solemn prayer of the village folk beseeching God to bless Poland. The prayer ends with the repeated acclamation of "Amen". This suggestive evocation of folk piety seems to be a highly pertinent way of depicting the Polish society. In this scene, the authors go beyond the stereotype of dramatic representation.

EXAMPLE 2 Polenblut - prayer of the country folk ${ }^{9}$

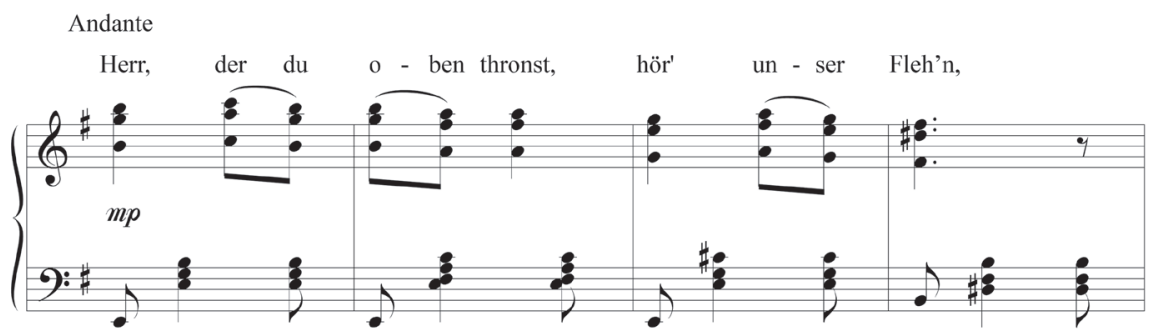

streu' aus dem Füll-horn aus, Glück und Wohl - er - geh'n!
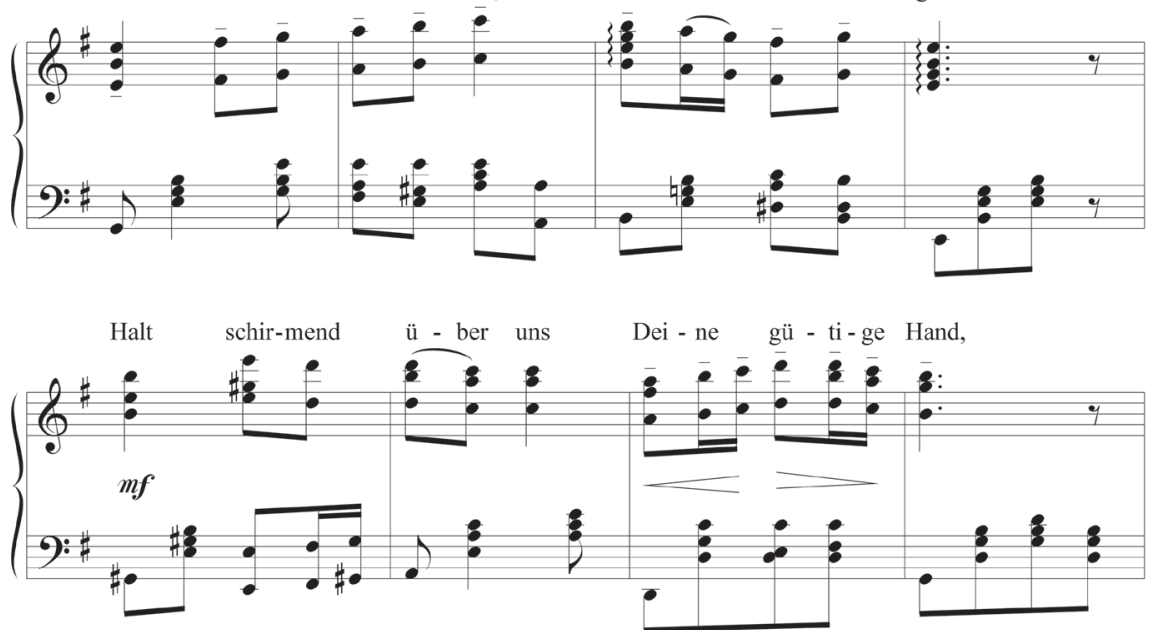

schüt - ze und seg - ne du un - ser Po - len - land!

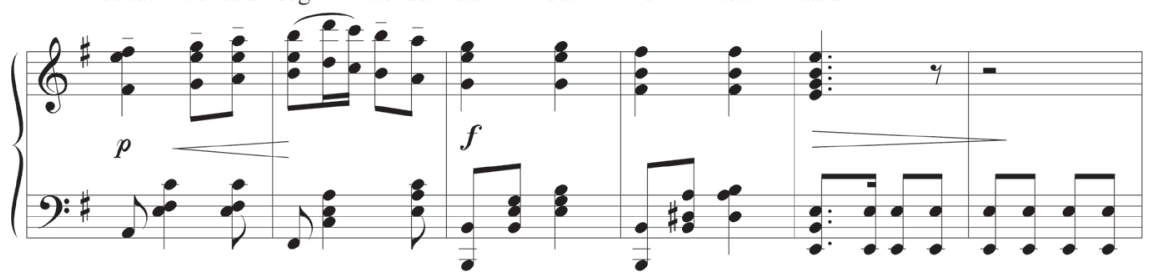

9. Bild 3, no. 12: Ensemble und Gebet. Source: Nedbal and Stein, Polenblut, 62. 
Example 3 Die blaue Mazur - Julian's dumka ${ }^{10}$
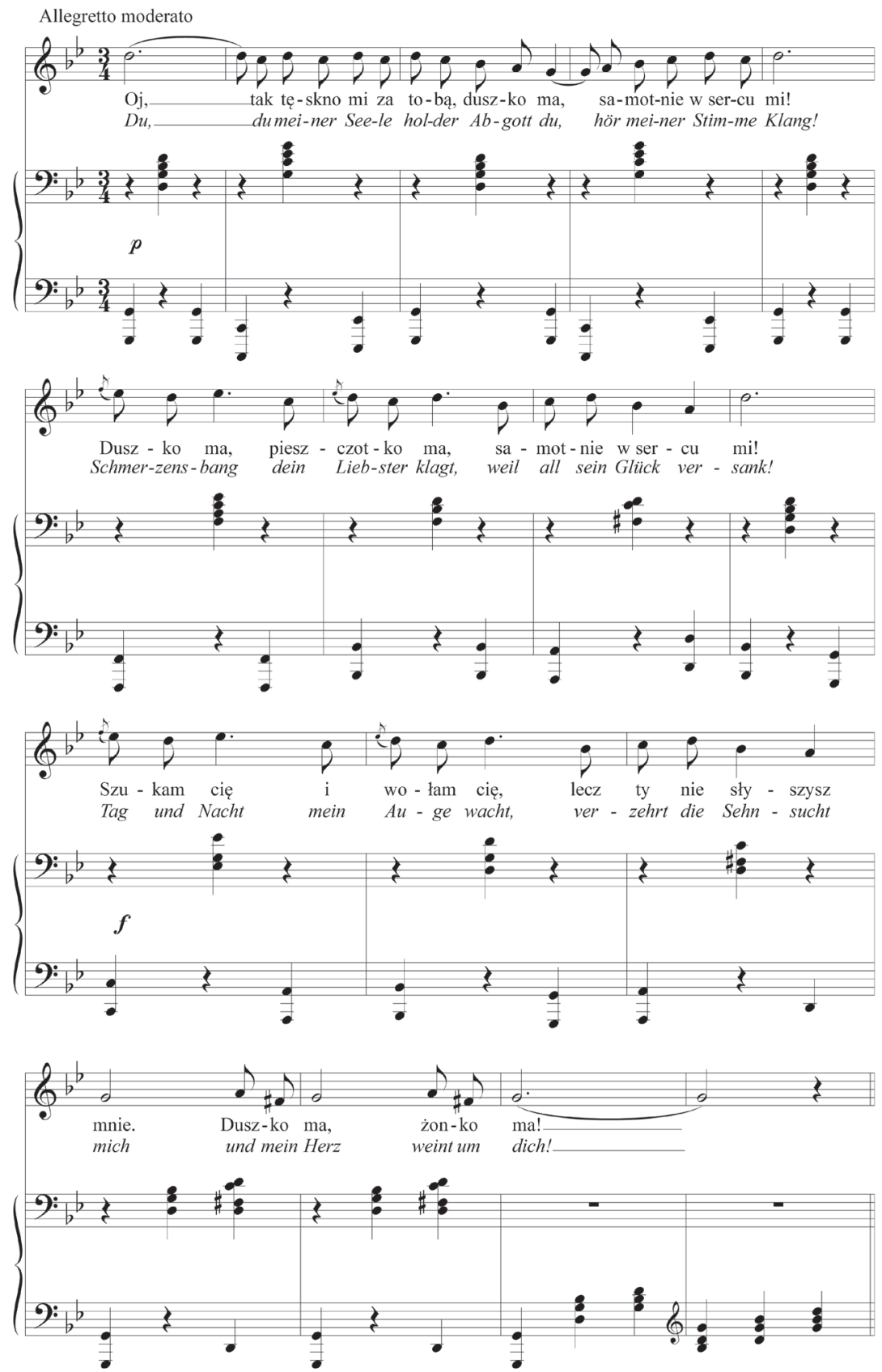

10. Act I, finale (no. 6). Source: Stein, Jenbach and Lehár, Die blaue Mazur, 53. 
The already mentioned dumka sung by Julian in Die blaue Mazur is similarly original in character. It not only consistently employs the Polish text, but also offers an example of refined stylisation akin to frontier-land songs of the Ukraine.

Research into the mechanisms of creating national stereotypes within bourgeois culture is in every respect relevant to an understanding of the contemporary perception of one nation by another. Though centuries of contacts between Poles and Germans offered plenty of opportunities for the two neighbours to get to know each other, complicated historical experience has given rise to all kinds of prejudices and oversimplifications. In this age-old cultural discourse, the German-language operetta played a significant part, becoming a sensitive barometer of social attitudes. The attraction of the operetta in its heyday depended on its role as a record and document of life, which was particularly important at a time when the modern media of mass communication were only beginning to form. The three stage works discussed in this paper, created in a period of historical transformation associated with Poland's rebirth as an independent country, appear to offer excellent arguments in the ongoing debate on the role of national stereotypes in communication between neighbouring nations. These forgotten operettas reflect the full spectrum of aspects related to the cultural frontier. 